\title{
The Pedagogical Attraction of Terentian Dramaturgy
}

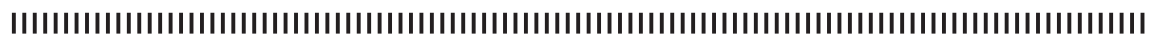
Sophia Papaioannou

Since Cicero's time and all the way to the modern era, Terence's plays have been studied for their pedagogical value, located in three particular areas. Foremost, Terence's works were valued for their choice of language and charm of style (cf. Cicero ad Att. 7.3.10 elegantiam sermonis; also Quintilian, inst. 10.1 .90 praised Terence's prose as in hoc genere elegantissima). From the Renaissance on Terence was a reference source of correct colloquial Latin. Secondly, Terence's characters were distinguished by their 'humanity', meaning their idealized depiction of human character, and were interpreted as exempla of civic conduct and morality. Thirdly, Terence invented the concept of suspense in a dramatic performance. By eliminating from his plays information about the resolution of the plot, and, especially in the Hecyra, by abolishing the traditional plot as such, Terence inspired the rebirth of drama in the modern era. Two less studied aspects of Terence' dramas, with respect to pedagogical interest, comprise their firm awareness of contemporary politics and social tensions, and tendency to assess and illustrate them. In the present paper, I discuss the different ways in which Terence's plays engage a) in critical dialogue with the conventions of comic dramaturgy and stereotypical characterization, and b) in socio-political commentary of issues of broad public interest, even though he reproduced the allegedly apolitical plots of Menander's dramas. Following an overview of the background of Terence's work (his predecessors and the characteristics of his dramaturgy that set him apart from the earlier masters of the palliata genre, most notably Plautus), and his special attraction to Menander, I will focus on two case-studies that illustrate how Terence's engagement with dramaturgical conventions and traditional, firmly established social norms may have been employed to provoke, but also educate and instruct.

I. Introduction. Terence, the earliest Roman writer whose corpus of literary production has survived intact, is widely acknowledged to have enjoyed uncontested popular acclaim during his brief (only six-year long, from 166 to $160 \mathrm{BCE}$ ) career as a comic dramaturge. Even though he is often cited for his repeated effort to stage his Hecyra (a play that was interrupted twice before it was finally performed in full, due to the audience's inability to appreciate properly the innovative experimentation with the traditional palliata norms introduced by the playwright in his last-to-final comedy), another one of his plays, the Eunuch, received an encore performance on the same day it was first brought to stage. The same play, according to Suetonius' biography of Terence, secured for Terence the unprecedented fee of 8,000 nummi (ca. 32, 000 sesterces). In later centuries, however, it was not his nerve as dramatist but the language and style of his texts that would elevate 
Terence to a must-read, whose popularity may be compared only to that of Vergil. Language and style worked jointly with diction that was marked by moral excellence. According to Donatus, Terence's ancient commentator, Terence stages characters who instruct with their behavior on what is useful in life and what ought to be avoided ${ }^{1}$. He also instructs proper behavior by satirizing human vices and the corrupt customs of the times ${ }^{2}$. Along the same lines, he numerous sententiae interspersed in all Terentian comedies offer profitable instruction through moral precepts.

Terence became an established literary authority with primarily pedagogical value during the fourth and the fifth centuries, a classic for the aspiring scholar to study and master, not only for its exemplary Latin but also for the philosophy of life transcribed in his verses. This combination of stylistic exemplarity and humanistic ideas secured Terence's survival through the Middle Ages, and guaranteed his enthusiastic embrace by the scholars of the Renaissance and Humanism later on. At the same time, the world of lovesick but also philandering youths, fathers both austere and lenient but too often foolish, courtesans with strong opinions and convincing worldviews, and wives at times querulous and at times victimized, annoyed some teachers, especially in the Middle Ages and the Early Humanistic period, but these same qualities were the very reason both schoolboys and intellectuals found Terence particularly attractive ${ }^{3}$. In the following pages, I shall discuss the pedagogical aspect side of Terence's work, and the great appeal it may exercise over audiences familiar with the technology of the comic genre and the ideology of Roman society of the Middle Republican period, founded as it were on the realistic and comprehensive treatment of actual social issues and civic norms, which were tackled with verisimilar emotion, pragmatism and humor.

The pedagogical attraction of Terence's style and morality has been amply studied in the past century. On the contrary, little attention has been paid to the technology determining the composition of Terence's dramas in terms of pedagogy. In other words, how was Terence's experimental treatment of traditional comic norms profitable for the student of Roman drama and its tradition? The textuality of Terence's dramatic verse and the pedagogical value it may carry, will be the focus of the present

\footnotetext{
${ }^{1}$ Donatus, ad Adelphos, praefatio 1.9.

${ }^{2}$ Donatus, ad Eunuchum, praefatio 1, 9, 232, 244.

${ }^{3}$ On the popularity of Terence in the Early Renaissance see, e.g., Tavoni, Mirko 1984. Latino, Grammatica, Volgare: storia di una questione umanistica. - Padova: Antenore (Medioevo e umanesimo 53). - P. 3-72, 105-116; Villa, Claudia. 1983. La 'Lectura Terentii'. - Vol. 1. Padua: Antenore. - P. 263-271; Bloemendal, Jan. 2003. Spiegel van het dagelijks leven? Latijnse school en toneel in de noordelijke Nederlanden in de zestiende en de zeventiende eeuw. - Hilversum: Verloren. - P. 32-41.
} 
paper. I shall discuss the different ways in which Terence's plays engage a) in critical dialogue with the conventions of comic dramaturgy and stereotypical characterization, and b) in socio-political commentary of issues of broad public interest, even though he reproduced the allegedly apolitical plots of Menander's dramas. Following an overview of the background of Terence's work (his predecessors and the characteristics of his dramaturgy that set him apart from the earlier masters of the palliata genre, most notably Plautus), and his special attraction to Menander, I will focus on two case-studies that illustrate how Terence's engagement with dramaturgical conventions and traditional, firmly established social norms may have been employed to provoke, but also educate and instruct.

II. Terence and His 'Controversial' Work. The comedy of Terence, "the last pioneer of the ancient stage" ${ }^{1}$, is the product of a long literary tradition that begins in Classical Greece with Old Comedy, undergoes gradual transformation in the next century, and through diffusion and dissemination across the Hellenistic world reaches Rome and initiates a thorough revision of native dramaturgy. The six plays that survive under Terence's name draw on this rich tradition, inasmuch as they comprise products of a literary genius that aspires to add a dimension of freshness and authenticity to the history of appreciation of the comic genre ${ }^{2}$.

Terence came at the end of the most widely acknowledged phase of comic dramaturgy at Rome. Starting with Livius Andronicus, the Romanized transformation of the New Comedy tradition at Rome was dynamic and ongoing for three generations, and by the time Terence asked the Roman magistrates to buy his Andria in $166 \mathrm{BCE}$, it had acquired a set plot-structure which nonetheless promoted diversity in the development of the plot, thus establishing a variety of different patterns. This plot-structure was executed by a standard set of acting characters led by the callidus servus, a charac-

\footnotetext{
${ }^{1}$ Goldnerg, S.M. 1986. Understanding Terence. -Princeton: Princeton University Press. - P. 153.

${ }^{2}$ The critical reception of Terence's interaction with tradition and the question of originality in Terence's plays, have always been remarkably polyphonic; cf., for example, the diversity in the assessment of Terence's originality by early scholars as summarised in Duckworth, George. 1952. The Nature of Roman Comedy: A Study in Popular Entertainment. - New Jersey: Princeton University Press. - P. 385-6. More recent criticism has been no less diverse, though critics nowadays tend to acknowledge the subtlety and sophistication of Terence's artistry; cf.e.g. Sharrock, A.R. 2009, Reading Roman Comedy: Poetics and Playfulness in Plautus and Terence. Cambridge: Cambridge University Press. - P. 201; Goldnerg, S.M. 1986. Understanding Terence. - Princeton: Princeton University Press, chapter 6; Wright, J. 1974. Dancing in Chains: The Stylistic Unity of the Comoedia Palliata (Papers and Monographs of the American Academy in Rome 25). - Rome: American Academy. - P. 127.
} 
ter who in the hands of Plautus, the highly gifted master whose works defined the palliata genre, habitually becomes the playwright's self-projection in his works. Upon realizing the considerable challenge entailed in the effort to outdo Plautus in the composition of plays along the lines of Plautine dramaturgy, Terence by and large played out against the background of the social and comic stereotypes established in the theatre of Plautus ${ }^{1}$. Thus, he re-invented comedy, on the one hand by engaging in systematic, self-conscious undoing of the Plautine characterization and technology of plot-development ${ }^{2}$, and, on the other by developing a style distinctly different from that of Plautus, which reached back to Menander. Unlike Plautus who had drawn inspiration indiscriminately from a variety of Greek playwrights, including Menander but also Philemon and Diphilos, to Greek authors distinctly different from Menander, and developing a markedly idiosyncratic style of dramaturgy, Terence strove to emulate solely the comedy of Menander (and Menander's most enthusiastic follower, Apollodoros of Carystos), both in style and in plot-structuring.

III. Menander, the civic pedagogue. Recent studies on Menandrian comedy have amply illustrated its political character and complex engagement with contemporary Athenian society and law, which it systematically criticizes, often quite conspicuously, but always with subtle humor. A typical such obvious commentary of Athenian family law, the law of the epiklèros ${ }^{3}$, stands at the core of the plot of Menander's Aspis. Athenian law dictated that an orphaned girl should come under the custody of her eldest male relative on her father's side, who in turn had the obligation either to marry

\footnotetext{
${ }^{1}$ See the discussion in Sharrock, A.R. 2014. "The Corrective Reader and Innovator", in S. Papaioannou (ed.), Terence and Interpretation, 119-42. - Newcastle: Cambridge Scholars Publishing, on instances of Terence's inventive 'interpretation' of Plautus. ${ }^{2}$ Sharrock, A.R. 2014. "The Corrective Reader and Innovator", in S. Papaioannou (ed.), Terence and Interpretation; Papaioannou, S. 2014. “Terence's Stock Characters \& Plots: Stereotypes Interpreted", in S. Papaioannou (ed.), Terence and Interpretation, 143-75. Newcastle: Cambridge Scholars Publishing. - P. 142-175. ${ }^{3}$ On the law of the epikleros in fifth and fourth century Athens see e.g. Harrison, A.R.W. 1968. The Law of Athens (i): The Family and Property. - Oxford: Clarendon Press. - P. 9-12, 132-8; Karnezis, J.E. 1977. "Law in the Aspis", Platon 29: 152-5; MacDowell, D.M. 1978. The Law in Classical Athens. - Ithaca, NY: Cornell University Press. - P. 103; Schaps, D.M. 1979. Economic Rights of Women in Ancient Greece. Edinburgh: Edinburgh University Press. - P. 25-47; Just, R. 1989. Women in Athenian Law and Life. - London/New York: Routledge. - P. 83-9, 95-8, on Isaeus 11.1-2, and Demosthenes 51.54; Cox, C.A. 1998. Household Interests: Property, Marriage Strategies, and Family Dynamics in Ancient Athens. - Princeton: Princeton University Press. P. 94-9; Cudjoe, R.V. 2000. The Social and Legal Position of Widows and Orphans in Classical Athens. PhD Dissertation, University of Glasgow; Cudjoe, R.V. 2006. “The Purpose of 'epidikasia' for an 'epikleros' in Classical Athens”, Dikē 8: 55-88.
} 
her himself or to find for her a husband, so that the oikos (household) of the girl's father may survive ${ }^{1}$, but, no less importantly, the girl find a new kyrios (legal guardian) and receive legal protection, given that women in the Greek antiquity did not have the franchise but rather were considered before the law as minors always to be under some guardian. But this is not all: the same law also stated that if the nearest of kin did not wish to marry the epiklēros, he ought to give her in marriage (presumably to the next of kin) with a dowry, in addition to what the woman had inherited from her father. On the basis of the available evidence, the marriage of an epiklēros with property did not require further legal intervention. It was the marriage of an orphaned daughter of the poorest classes with no male siblings that posed a problem in need of legal attention.The lower the class of the epiklerros, the higher the sum of the dowry to be supplied by the successful claimant; and the higher the class of the nearest of kin who did not wish to marry her, the higher the sum he had to pay $^{2}$. In the Aspis, Menander exercises criticism on the particular law which ignores possible alternatives, better suited to the particular situation, by staging a greedy old man becoming at the same time the kyrios of his two nieces, the one richer than the other, and deciding to wed the wealthier of the two, while originally he strove to make his case for the other one. At the same time, the same criticism offers subtle yet clear instruction for the politically minded, by urging for necessary amendments on a law that in Menander's day is nearly a century and a half old, and evidently not meeting the needs of the author's contemporary social experience $^{3}$. Menander's tactful mode of instruction, his ability to entertain and

${ }^{1}$ Cudjoe, R.V. 2006. "The Purpose of 'epidikasia' for an 'epikleros' in Classical Athens", Dike 8: 55-88. - P. 76, with Ath. Pol 56.6.

${ }^{2}$ The law is quoted verbatim and in detail in Dem. 43.54; other attestations of epiklēros law include Is. 3.64, 74; 6.14; Demosthenes 43.5, 16; 46.18, 22, 23; 57.41; [Aristotle] Athēnaeon Politeia 43.4; Andokides 1.117-21; cf. Cudjoe 2006, 59; notably, Demosthenes 43.54 records "the only public law that carefully monitored the marriage of the poor epiklerros" [Cudjoe, R.V. 2006. "The Purpose of 'epidikasia' for an 'epikleros' in Classical Athens”, Dikē 8: 55-88. - P. 60].

${ }^{3}$ On the ways in which Menander engages in substantial political and cultural negotiation with contemporary issues, see, e.g., Lape, S. 2004. Reproducing Athens: Menander's Comedy, Democratic Culture, and the Hellenistic City. - Princeton: Princeton University Press; Lape, S. 2010. "Gender in Menander's Comedy", in A. Petrides and S. Papaioannou (eds.), New Perspectives on Postclassical Comedy, 51-78. - Newcastle: Cambridge Scholars Publishing; Konstan, D. 2010. "Menander and Cultural Studies”, in A. Petrides and S. Papaioannou (eds.), New Perspectives on Postclassical Comedy, 31-50. - Newcastle: Cambridge Scholars Publishing; Traill, A. 2008. Women and the Comic Plot in Menander. - Cambridge: Cambridge University Press; McGlew, James. 2002. Citizens on Stage: Comedy and Political Culture in the Athenian Democracy. - Ann Arbor: University of Michigan Press. 
at the same time educate his audience by introducing civic concerns of the body politic, find a fine successor in Terence, who became greatly popular throughout Antiquity no less on account of the educational dimension of his plays ${ }^{1}$.

IV. Interpreting Terence, the pedagogue: two case-studies. Roman comedy among other things offers a critique of the Roman civic experience: it became so popular because, being aligned with the spirit of the ludi, the Roman festivals during which dramatic performances were delivered, it celebrated on stage the spirit of the Saturnalia, calling for the inversion of real life, and the transgression of social and gender norms ${ }^{2}$. For Plautus, the inversion of social orthodoxy became an ideal host for multilayered farce and experimentation with various modes of meta-dramaturgy. For Terence, who follows after the paradigm of Menander, it offered an opportunity to indict practices and norms that were socially and politically sanctioned, yet highly oppressive and harmful for a considerable part of the Roman populace: patriarchy, slavery, promiscuity, rape, sexual and class inequality, the practice of child abandonment. Terence's plots generate laughter by staging characters acting unlike their normal selves and in doing so demonstrating the way in which cultural constructs exploit the frailty of the human condition. In this respect, Terence's drama is uniquely instructive, and his plays became a school-text sometime in the second half of the second century BCE - if we believe Cicero (born 106 BCE) who writes that he had studied Terence's plays as a boy ${ }^{3}$. And despite radical chances in the cannon of literary classics in the grammarians' curricula in the following centuries, with the Augustan authors displacing their Republican predecessors, Terence remained a core school author throughout the imperial period, and by the late fourth century he had become, along with Cicero, Sallust and Vergil, one of the four main canonical school authors ${ }^{4}$. Roman school children began their formal study of Terence under the instructions of a grammaticus, an instructor expert in the Latin language and literature, who guided the pupils in word-by-word analysis of the play,

\footnotetext{
${ }^{1}$ On Menander in the school curricula in Antiquity, see now: Nervegna, S. 2013. Menander in Antiquity: The Contexts of Reception. - Cambridge: Cambridge University Press. - P. 201-250.

${ }^{2}$ Segal, E. 1987. Roman Laughter. The Comedy of Plautus. Second Edition. - Oxford and New York: Oxford University Press. discussion the comedy of Plautus.

${ }^{3}$ Bonner, Stanley Frederick. 1977. Education in ancient Rome from the elder Cato to the younger Pliny. Berkeley and Los Angeles: University of California Press. - P. 261. ${ }^{4}$ On this canonical literary tetrad, see Cassiodorus Inst. 1.15.7.
} 
and complementing grammatical observations with comments on meter, style and vocabulary ${ }^{1}$.

a. Instructing plot de-structure: the script-less Hecyra. By the later centuries of the Late Antiquity the well-educated elites had a copy of Terence's plays in their libraries ${ }^{2}$. A distinct such case is that of the fifthcentury Gallic bishop Sidonius Apollinaris who writes in one of his letters of the quality time he spends with his son in the evenings reading Terence together ${ }^{3}$, "Nuper ego filiusque communis Terentianae Hecyrae sales ruminabamus; student assidebam naturae meminens et professionis oblitus quoque absolutius rhythmos comicos incitata docilitate sequeretur, ipse etiam fabulam similis argumenti id est Epitrepontem Menandri in minibus habebam. Legebamus periter laudabamus iocabamurque et, quae vota communia sunt, illum lectio, me ille capiebat, cum repente puer familiaris adstitit..." (Sid. Apoll. Epist. 4.12.1-2) .

"A few days ago, I and the son whom we both regard as ours were browsing on the wit of Terence's Hecyra. I was seated beside him as he studied, following my natural inclination and forgetful of the formalities of my sacred calling; and in order to spur his receptive mind and enable him to appreciate the comic rhythms more perfectly, I had in my own hands a play with a similar plot, the Epitrepontes of Menander. We were reading, and at once jesting and applauding, and, such are the desire we all share, he was charmed with the reading and I with him, when suddenly a slave of the household showed up..."

Sidonius' letter describes the scene of a father supervising the study of his son and instructing the latter's introduction to Terence. Sidonius was particularly well-acquainted with Terence's works ${ }^{5}$, and he evidently knew Menander no less intimately, judging from his reference to his own

${ }^{1}$ On the profession of the grammarian and the education he provided in detail see: Kaster, Robert. 1988. Guardians of Language: The Grammarians and Society in Late Antiquity. - Berkeley: University of California Press, esp. 32ff.

${ }^{2}$ On Terence's continuous and widespread presence in the educational curricula throughout the Late Antiquity see: Cain, A. 2013. "Terence in Late Antiquity”, in A. Augoustakis and A. Traill (eds.), A Companion to Terence. 380-96. Malden, MA, Oxford and Chichester: Wiley-Blackwell, chapter 20.

${ }^{3}$ See commentary by Amherdt, David. 1999. Sidoine Apollinaire, Le quatrième livre de la correspondance: Introduction et commentaire. - Bern et alib.: Peter Lang. P. 309-314.

${ }^{4}$ Sidonius' text and translation (with adaptations) are taken from Anderson, W.B. (ed. and transl.) 1965. Sidonius. Letters, Books 3-9. - Cambridge, MA: Harvard University Press (Loeb Classical Library, 420).

${ }^{5}$ Harries, J. 1994. Sidonius Apollinaris and the Fall of Rome, AD407-485. - Oxford: Oxford University Press. - P. 39. 
reading of Menander's Epitrepontes (The Litigants), at the same time his son is studying Terence ${ }^{1}$. Indeed, Sidonius' statement describes a complex assessment of Terence's Hecyra (The Mother in Law). Father and son appreciate the play from multiple different perspectives: they jointly study form (meters) and comedic content (they both laugh and find the content witty), while Sidonius a leading scholar of his age, likely attempts a comparative study of the Hecyra to Menander's Epitrepontes, and possible instructs his son in intertextual comparative criticism as well. The plot of the Epitrepontes in reality is very similar to that of the Hecyra, and, no less, the social commentary both plays exercise has much in common ${ }^{2}$. Both plots develop around the estrangement of a married couple on account of the birth of a baby by the wife, whose paternity the husband contests. In the end, of course, it is revealed that the husband is really the father, who had impregnated his (not yet at the time) wife by force (rape) while intoxicated, at night, and without knowing the identity of his victim.

The plot of the Greek play is considerably elaborate: the wife in Menander's play, the young wife Pamphile, abandons the baby in the woods (with certain special jewels so that someday it might be able to prove its identity), as the baby was born during her husband's absence abroad. Yet, her act is intercepted by a slave, Onesimos, who discloses this information to his master and the lady's husband, Charisios. The disclosure brings about a family crisis. Astonished and enraged at his wife's alleged infidelity during his absence, Charisios moves out of his household and in with his next-door neighbor and friend, and he hires a young and beautiful prostitute, Habrotonon, as his escort. In reality, however, Charisios never stops loving his wife, and when he is alone and out of public sight he laments without end for his broken marriage, with Habrotonon playing the part of the sympathetic audience.

Terence's young husband Pamphilus, in turn, seems to experiment with civic and social (family) norms throughout the play, offering the clearminded student an opportunity to identify and assess several dilemmas, concerning both his dramatic character (the young husband who suspects his wife for infidelity) and his dramatic identity (the lack of a previous model that fits exactly his circumstances). When the play begins, we learn,

\footnotetext{
${ }^{1}$ A little earlier, in early fourth-century Gaul, Ausonius, Sidonius' teacher, recommended to his grandson to read Menander along with Homer (Epist. 22.45-50). ${ }^{2}$ Allegedly a model of the Hecyra through Apollodorus; cf. Duckworth, George. 1952. The Nature of Roman Comedy: A Study in Popular Entertainment. - New Jersey: Princeton University Press. - P. 149. For Terence's Hecyra in its relation to Menander's Epitrepontes, cf. esp. Penwill, J.N. 2004. “The Unlovely Lover of Terence's Hecyra", Ramus 33: 130-49. - P. 146 and n. 45.
} 
from the narrative of the courtesan Bacchis that he is deeply and genuinely in love with her (Bacchis is a representative expression of the Terentian comic character of the bona meretrix, the good-hearted courtesan). Eventually he is 'persuaded' by his father, Laches, to marry Philumena, a young lady of Athenian citizenship, thus abiding to the social norm often celebrated by New Comedy plots ${ }^{1}$. The young man weds Philumena, and even though initially he refused to consummate the marriage (135ff.; 145 : narratque ut virgo ab se integra etiam tum siet) because he is not in love with his young wife and treats her with contempt (though he is not physically abusive) (cf. 1l. 164-6). As he realizes, however, that Philumena is bearing this contempt with civility and private dignity, never disclosing anything to a third part and never uttering a complaint, Pamphilus grows warm to her and falls in love. And eventually consummate their marriage ${ }^{2}$. Upon Pamphilus' departure to Imbros for a legacy issue, Philumena invents a pretext to leave her husband's house. There starts a series of misunderstandings and misconceptions constructing the plot of the comedy, according to the 'generic standards' of the Hellenistic and Roman comic genre. No intradramatic character knows why Philumena left, and most importantly for the purposes of the palliata genre, no information is offered at the beginning of the play, either by some informative monologue either in the form of a protatic dialogue. Some of the characters in the play are of the view that Sostrata's bad manners towards her daughter-inlaw may account for Philumena's going away. They conclude so misled by their 'knowledge' of the behavior of young wives in similar circumstances, either in real life or on the palliata stage (the mothers-in-law are typically matrons austere and authoritative, who boss around everybody in the household, male and female, including their own husbands, as Plautus' Sostrata [Casina] and Menaechmus Sosicles' wife [Menaechmi] have amply illustrated). On the other hand, the young wife Philumena does not have a literary model to draw instruction thereupon: she realizes that she has become pregnant, and she wishes to conceal this pregnancy because it is the outcome of a rape that happened prior to her marriage and prior to the opening of the drama. Even though the father of the baby is Pamphilus himself, Philumena does not consider sharing this information with him

\footnotetext{
${ }^{1}$ Cf. Konstan, D. 1983. Roman Comedy. - Ithaca, NY: Cornell University Press; see also Penwill, J.N. 2004. “The Unlovely Lover of Terence's Hecyra”, Ramus 33: 131-2. ${ }^{2}$ Hec. 169-70: paullatim elapsust Bacchidi atque huc transtulit / amorem, postquam par ingenium nactus est. 'and little by little he sneaked away from Bacchis and transferred all his affection to his wife, especially since he realized that they two are likeminded'. Parmeno's description is hardly explicit but he suggestively implies the consummation of the marriage.
} 
and prefers to run away to her mother's house and reconsider her dramatic (and civic) identity there.

Even so, Philumena's decision to return to her parental house to reinvent her civic identity from a different perspective opposes civic ideology as promoted by the social outlook of New Comedy, namely the propagation of the oikos through a functional marriage. As Sharrock [(2013) 58] convincingly observes, "The bride Philumena's return to her natal family is a move away from comedy, with its structures of society-building interaction between families, and into tragedy, with its self-destructive, quasi incestuous families". The absence of a comic model, in other words, has led Philumena to make the wrong decision for a departure constitutes not only a moving away from standard comic 'generic rules' ${ }^{1}$ but also a kind of 'generic transposition' towards the tragic mode, which operates here through the image of a destroyed oikos and a 'self-destructive' family. And so that the audience may not miss this generic transposition (and be tested, even instructed in their readiness to identify Terence's interplay with variant genres), the slave Parmeno, who may not be a typical servus callidus (in the Plautine sense of the term) but is alert enough to spot divergences from the norms of the broadly expected plot, describes in detail Philumena's initial ill treatment by her husband, who, additionally, also deviates from comic 'generic rules'.

Philumena has not committed a fault (as perceived by Charisios concerning his wife's pregnancy in Menander's Epitrepontes), nor is in the couple involved a senex and a matron dotata, something which could justify a problematic marriage ${ }^{2}$. What is in fact developed here is an adulescensvirgo liaison which, however, has achieved its dramatic closure (marriage) at the outset of the play [Slater (1988) 251]. In this respect, Pamphilus, up to a point, deviates from the comic norm of an adulescens. To underscore the un-comic aspect of the play, Parmeno recourses to tragedy.

tundendo atque odio denique effecit senex:

despondit ei gnatam huius vicini proxumi.

usque illud visum est Pamphilo ne utiquam grave

donec iam in ipsis nuptiis, postquam videt

paratas nec moram ullam quin ducat dari,

ibi demum ita aegre tulit ut ipsam Bacchidem,

si adesset, credo ibi eius commiseresceret.

${ }^{1}$ Cf. also Traill, A. 2008. Women and the Comic Plot in Menander. Cambridge: Cambridge University Press. - P. 258-9.

${ }^{2}$ Cf. James, S.L. 1998. "From boys to men: rape and developing masculinity in Terence's Hecyra and Eunuchus”, Helios 25. - P. 45. 
In the end his father was so insistent and tiresome that he prevailed, and he arranged for Pamphilus to marry the daughter of our next-door neighbour here. This didn't seem particularly serious to Pamphilus right up to the actual time of the wedding. But when he saw everything was ready and that there was no reason now to postpone the marriage, then finally he was so upset that I believe even Bacchis herself would have pitied him, had she been present ${ }^{1}$.

Lines 128-9: ut ipsam Bacchidem, si adesset, credo ibi eius commiseresceret have been, most probably, fashioned after Pacuvius, trag. 391 $\mathrm{R}^{3}=213$ D'Anna = 294 Schierl: Priamus, si adesset, ipse eius commiseresceret ('if Priam were here, even he would pity him') ${ }^{2}$. In Pacuvius, the toils plaguing the Greek army on their way home from Troy allegedly would cause even Priam, their Trojan enemy and eventual victim, to feel pity for them. Evidently the phrase must have become a proverbial one for extreme suffering $^{3}$, and the humorous effect it causes when is employed by Bacchis to describe the potential sympathy for Pamphilus, the despaired husband in a forced marriage, is conspicuous, especially in light of Pamphilus' consent for a lawful wife, after all ${ }^{4}$.

b. 'My father, the pedagogue': dissertating on the self-profiling of the father as educator in the Adelphoe. The Adelphoe, the last of Terence's plays, is a play about pedagogy and education on more than one level. Ostensibly it is about the education of young men. At the same time, it details the different educational approaches respectively of two fathers, it introduces and assesses their childrearing practices and theories, and suggestively describes how they themselves are taught new things about childrearing from their sons and from each other. Further, the juxtaposed methodologies of parenting adopting by the two fathers (who also happen to be brothers) pit the traditional and strict (Roman) form of education against a more

${ }^{1}$ Translations of Terence's text follow Barsby, John (ed. and transl.) 2001. Terence. Phormio. The Mother-in-Law. The Brothers. - Cambridge, MA: Harvard University Press. (Loeb Classical Library, 23).

${ }^{2}$ Translated by Warmington, E.H. 1936. Remains of Old Latin, vol. 2: Livius Andronicus, Naevius, Pacuvius, Accius. Loeb Classical Library. - Cambridge, MA and London: Harvard University Press and Heinemann. - P. 309; see the argument in full in Karakasis, Evangelos. 2014. "Tragic and Epic Interactions in Terentian Comedy”, in S. Papaioannou (ed.), Terence and Interpretation, 75-93. - Newcastle: Cambridge Scholars Publishing. - P. 88-89.

${ }^{3}$ It recurs in Vergil, Aeneid 11.259 [cf. Schierl, P. 2006. Die Tragödien des Pacuvius. Ein Kommentar zu den Fragmenten mit Einleitung, Text und Übersetzung. - Berlin and New York: De Gruyter. - P. 561].

${ }^{4}$ Cf. also Ireland, S. (ed. and transl.) 1990. Terence: The Mother in Law. - Warminster: Aris and Phillips. - P. 114. 
lenient (Greek) form. The plot transcribes the love intrigues of two young men, biological brothers, but reared in different homes. Demea, the biological father of both, gave one of his sons, Aeschinus, to his brother Micio, a bachelor who advocates a less traditional, more compassionate method of raising one's child. In contrast, Demea is rearing his other son, Ctesipho, in strict authoritarian style. The two younger brothers, who are very close, are both involved in amorous affairs, and the way they handle them is determined by their upbringing. Aeschinus, the youth raised by the liberal father, is certainly the leader, and even though his conduct is not impeccable, the genuineness of his love for his brother and the determination he shows on his brother's behalf, wins over even the austere Demea.

In constructing the characters of the fathers Demea and Micio Terence wittingly takes on Cato the elder, the most influential political figure of his times and an intellectual in his own right, whose political eminence determined the definition of proper civic morality in the Middle Republic, while his writings comprise the earliest pieces written in Latin prose, the agricultural treatise, De agri cultura, and the historiographical work Origines in 7 books, so much so that he is generally considered the father of Latin prose, didactic and historiography alike. The treatise De agri cultura, is likely the handbook (hypomnema) referred to in Plutarch (Cato Maior 33-4), which the great Roman wrote for the management of his familia. Cato published his notes clearly considering that his household management would serve as an exemplum of instruction and, more importantly, in the detailed description of the way he treats his slaves, his wife and his son, Cato would offer the Romans an agricultural and economic exemplum for the rest of his compatriots widely accessible having been composed in Latin.

Exemplarity, the direction of one's own conduct on the basis of a paradigm sits at the core of traditional Roman morality - the mos maiorum of the Early Republic - which is advertised as the method par excellence for instructing one's children in morals and lifestyle by Demea, the traditionalist brother in the Adelphoe. Since there were no formal educational institutions or even the technology of writing to record ancestral excellence, the Early Republicans instructed their sons by producing exempla, heroes of the Early Republic who had distinguished themselves for their exemplary performance of the values comprising the mos maiorum ${ }^{1}$.

${ }^{1}$ Bonner, Stanley Frederick. 1977. Education in ancient Rome from the elder Cato to the younger Pliny. - Berkeley and Los Angeles: University of California Press. P. 18. These mores (morals) included, among others, virtus (courage, bravery but also moral virtue), industria (diligence), constantia (determination), parsimonia (austerity, frugality), gravitas (self-control), pietas (piety, reverence, deference), fides (trust) and severitas (strict discipline). 
Additionally, and thanks to Cato's works, the Roman father, the paterfamilias, could be considered himself an exemplum for his son ${ }^{1}$. Cato, in addition to his handbook on agriculture, wrote a handbook for the education of his own son, Licinianus, because he decided to educate the young man himself rather than hand him over to the grammarian Chilon, who was both a slave and Greek (Plutarch, Cato Maior 2.20, with Bonner 1977, 10).

Terence models Demea on Cato: as if following to the letter the paradigm of the great Roman statesman, Demea proudly declares his employment of exemparity as the preferred method of educating Ctesipho:

fit sedulo. nihil praetermitto; consuefacio; denique inspicere tamquam in speculum in vitas omnium iubeo atque ex aliis sumere exemplum sibi. (Ad. 415-16)

One does one's honest best; I pass nothing over; I train him; in short, I tell him to look into people's lives as if into a mirror and to take his model from others.

Similarly, Cato dictated to his son a lifestyle determined by the ancestral mos maiorum and based on hard agricultural labor, life in the country, obedience to the father, and abstinence from the comforts of civilization. According to the Twelve Tables, the ancestral code of private law dating as early as the $4^{\text {th }} \mathrm{c}$. BCE, a father had the right to punish his sons severely for nonconformity to the mores maiorum "of frugality, work, discipline and piety"2. At the same time, Demea distinctly dictates to his son what the youth should do, evidently does not trusting him to be able to behave properly without specific instruction: "hoc fugito" ('Always avoid that'). "hoc laudist" ('This is a source of praise!'). "hoc vitio datur" ('That counts as a vice')" (Ad. 416-17). Micio takes great pains to talk about his own son's adherence to the hard and frugal life of the country and his avoidance of luxuria, the beginning of the end for traditional Roman morality and the decline of the commonwealth. He criticizes Micio and Aeschinus for indulging in luxury complaining that Micio's household is addicted to luxury: it is a domus sumptuosa ('house of profuse expenses'), and that this lush upbringing is a primary reason that he has lost Aeschinus to luxury: Ad. 760: adulescens luxu perditus ('the youth has been ruined by

\footnotetext{
${ }^{1}$ Micio's words aptly capture Demea's own philosophy of life - and lifestyle no less: Ad. 45: haec omnia: ruri agere vitam, semper parce ac duriter se habere; uxorem duxit, nati fili (His entire life is summed up as follows: constant toil on the farm, the self-discipline of thrift and austerity; marriage; two sons). This description of Demea as a stern and frugal man is also provided by Demea himself: Ad. 86768: ego ille agrestis saevos tristis parcus truculentes tenax duxi uxoruem: quam ibi miseriam vidi!" (It was I, the very model of the peasant, harsh, brute, aggressive, tight-fisted, that took on marriage - and what distress I found in that!)

${ }^{2}$ Mellor, Ronald. 1999. The Roman historians. London: Routledge. - P. 19.
} 
luxury' $)^{1}$. Luxury pairs with lust and license in general (licentia), and this is indeed Demea's next preoccupation regarding the improper education his brother is providing to his own son: This preoccupation is reported through the works of Micio himself:

venit ad me saepe clamans 'quid agis, Micio? quor perdis adulescentem nobis? Quor amat? quor potat? quor tu his rebus sumptum suggeris, vestitu nimio indulges? nimium ineptus es! (Ad. 64-66)

He keeps coming here shouting 'Micio! What's the idea? Why spoil the boy and bring shame on us all? Why these girls? Why these wild parties? Why foot those bills, and pander to his grotesque ideas of style? ${ }^{2}$

Micio, on the other hand, embraces a different system of pedagogy, one determined by the social and cultural trends that took shape in Rome in the first half of $2^{\text {nd }} c$. BCE under the increasing influx and influence of Greek culture and ideology, as a result of the Roman expansion eastwards following the first and the second Carthaginian wars, and their growing intimacy with the mores of the Hellenistic East. Comparing the Greek and the Roman system of educating young men, Dionysius of Halicarnassus (Roman Antiquities 2.26) remarks that Greek fathers inflict light punishment upon their children, as a result, the latter grow up to disobedience and moral laxity. This never happens to the Romans because the paterfamilias does not hesitate to exercise the full authority of his potestas, even kill his child if the latter disregards his commands (and he produces as example Manlius Torquatus, who did not hesitate to order the death of his son who disobeyed his order to stay back and not attack the enemy, despite the fact that the youth's initiative secured a victory for the Roman $\mathrm{army}^{3}$. When, however, the influence of Greek culture infiltrated Rome, severitas gave way to a less overbearing type of parenting - this is to be deduced from the description of the relationship between father and son recorded in the text of later authors, from the $1^{\text {st }}$ c. BCE onwards. For example, in his defense of Caelius

${ }^{1}$ In the De agricultura 5, Cat instructed Roman farmers to purchase a rus (farm) that does not cost them a great deal of sumptus ('expenses') in order to avoid material indulgence (Videto quam minimi instrumenti sumptuosusque ager ne siet); and that even their meals should be simple and handy, stating that himself ate simple meals with turnips and bread (Plut. Cat. Mai. 25.1-3).

${ }^{2}$ Later in the play (508-510) Demea himself argues that the licentious lifestyle of Aeschinus would end up in ruin and he uses the word licentia here: verum nimia illaec licentia profecto evadet in aliquod magnum malum ('all that excessive license is bound to end in some dreadful disaster').

${ }^{3}$ For the father's power of life and death as a distinct feature of Romanness, see Thomas, Y. 1984, “Vitae necisque potestas", in Y. Thomas (ed.), Du Châtiment dans la Cité. Supplices Corporels et Peine de Mort dans la Monde Antique, 499-548. Rome: École Française de Rome, 503ff. 
Cicero dramatizes an address to the seductress Claudia, and asks her to choose which paternal persona Cicero should put on to deliver his address to her, the traditional one, of the strict and austere ancestor, or the more mild and gentle fashion of a contemporary parent (Pro Cael. 33). In the next century, Pliny the Younger argues that a father should be empathetic when deciding punishment for the immorality of youth because fathers were also young boys once ${ }^{1}$. His views echo similar to those of Micio, who in his opening monologue compares his own philosophy on child-rearing to that of his brother Demea, claiming that pudor ('shame') and liberalitas ('generosity') are more effective means of restraint than metus ('fear') (57-8) and that imperium ('orders') is more stable if it arises through amicitia ('friendship, kindness') than through vis ('enforcement') (65-7). The results of pudor, liberalitas, and amicitia are a son who will do the right thing sua sponte ('freewillingly') rather than through metus of another $(75)^{2}$.

V. Conclusion. Terence's text was an established manual for instruction since the days of Cicero's boyhood, less than a century after the dramatist's death, and continued unabated to feature in official academic curricula and less formal educational settings across the centuries. Focusing just on the appeal of Terence's Andria in more recent times, Peter Brown notes that "Andria" (The Girl from Andros) was Terence's first play, and also the first of his plays - indeed the first ancient Latin comedy at all - to be performed in the Renaissance, at Florence in 1476. It was the first Latin comedy to be translated into English, in the 1520s, and the first that is named as having been performed at Oxford, when the scholars of Trinity College put it on in 1559. It was translated into Italian by Ariosto and Machiavelli, into German by Mendelssohn. It was regularly performed at Westminster School in the eighteenth and nineteenth centuries and through to the 1930s, at a time when the Westminster Latin Play was one of the great social events of the year in London" 3 . Terence' attractiveness by educators and readers across the centuries was traditionally attributed to the purus sermo of the text, the employment of the proper form of colloquial Latin, but the playwright's novel approach on the conventions of comic dramaturgy and his insightful and tactful commentary on social issues of general concern and standing interest across time, may introduce new perspectives through which educators may use Terence's text to keep their audiences engaged with the study of the great Latin comic dramaturge.

\footnotetext{
${ }^{1}$ Pliny, Epist. 9.12.

${ }^{2}$ On educating through amicitia, liberalitas and pudor in the Adelphoe, see Comerci, G., 1994. "Humanitas, liberalitas, aequitas; nuova paideia e mediazione sociale negli Adlephoe di Terenzio", Bollettino di studi latini 24: 3-44.

${ }^{3}$ Brown, Peter. 2014. "Interpretations and Adaptations of Terence's Andria, from the Tenth to the Twentieth Century”, in S. Papaioannou (ed.), Terence and Interpretation, 241-265. Newcastle: Cambridge Scholars Publishing. - P. 243.
} 